\section{$3 \mathrm{~L} 1415$ \\ 心筋 SPOCにおける Connectin/Titin の働き}

○阿部 洋介、佐々木 大輔、石渡 信一（早大院 - 理工研 - 生 命理工)

心筋拍動は、ペースメーカー細胞からの電気的パルスによって制 御されている。一方、除膜横紋筋（心筋・骨格筋）はATP・ADP・ $\mathrm{Pi}$ 其存という溶媒条件下において、筋節長及び発生張力の自励振動 (ADP・SPOC) を生じる。SPOC 状態にある各筋節は、速い収樎相 と遅い伸長相からなる鋸蒾状の波形で周期的に振動し、伸長相は隣接 する筋節へ等速に伝播していく。本研究では、弾性タンパク質 Connectin/Titin (C/T) の心筋SP()Cにおける働きを調べる為に、SP()C 溶液に Trypsin を加えることによってC/T を切断し、SPOC 周期の 变化を調べた。また、C/Tの分解を途中で止める目的でTrypsin イン ヒビターであるLeupeptin(2m、I: ゚゚プチド研)を加えたSPOC 溶液を 準備し、SPOC 中に溶液置換を行った。筋線維束試料としてラット の左室乳頭筋を、実体顥微鏡下で $100 \mathrm{~mm}$ 程度の太さに筋線維に沿っ て注意深く裂き、TritonX-100 処理で除膜し、ガラス底シャーレ上に 長さ約 $1 \mathrm{~mm}$ になるように両面テープで両端を固定した。この心筋線 維束試料の表而に蛍光ビーズを付着させ、この軌跡を蛍光影微鏡で観 察・ビデオ記録し、往復並進運動周期を解析することにより、ラット の心筋 SPOC 振動周期を調べた。その結果、Trypsin 入りの SPOC 溶液では除々にSPOC 周期が長くなる事が確認された。骨格筋 SPOC には Trypsinの影響がないことから、骨格筋 SP()Cには C/Tは関与 していないと結論されている。しかし心筋に执いては、C/Tは静止 張力に大きく奇与しているたけでなく、SPOCにも関与しているよう である。一方意外な事に、2mM Le upeptinにSPOCの周期を短くす る効果がある事が確認された。現在その原因を検討中である。

Y.Abe,D.Sasaki,S.Ishiwata : Roll of Connectin/Titin in cardiac musre SPOC

\section{M0900}

\section{Dihydrolipoamide dehydrogenase の変性過程}

○目野浩:- ${ }^{1}$ 、西本悦子 ${ }^{2}$ 、古賀淑哲 ${ }^{3}$ 、山下昭二 ${ }^{1}$ ( ${ }^{1}$ 九大 院・農学系・植物資源、2 農生資、3 缠総研)

蛋白質の構造はペプチド部分間の凝集的な作用と、これを壊そうと する熱的な撜乱連動のバランスの上に成り立ち、後者が前者を上间る とき変性する力问に向かう。このような直感的なモデルに基づけば、 熱による変性と変性郕による变吽過程を比較してみるのは興味深い。 今回、好熱菌 B. stearothermophilus のピルビン酸脱水素酔素複合体 (PDC)の構成酵素である Dihydrolipoamide dehydrogenase (Lip-DH) を用いて、その熱変性と化学的変性過程を比較した。主に、Lip-DH の Trp 残基と FAD の蛍光特性に着目した時間分割営光法を用いた。 化学的変性作用にはグアニジン塩酸塩 $(\mathrm{GdnHCl})$ を用いた。

熱变性においては、NADの還元を指標とする醉素活性、CDにお ける棈円率の低下、FAD蛍光強度の上昇が、70 ${ }^{\circ} \mathrm{C} \sim 85^{\circ} \mathrm{C} の 30$ 分間の 熱処理で観測され、これらの変化の回復は認められなかった。即ち、 Lip-DHはこの温度領域で不叮逆的に変性した。一方、Trp 残基加ら $\mathrm{FAD} へ$ エネルギー移動効率は、 $30^{\circ} \mathrm{C} ー 50{ }^{\circ} \mathrm{C}$ 間は一定であるが、 $50{ }^{\circ} \mathrm{C} \sim 65{ }^{\circ} \mathrm{C}$ に加忛て著しく上昇し、その後 Lip-DHの不可逆的变性 に至る温度領域では再び低下した。また、時間分割蛍光異方性の解析 結果は、 $50{ }^{\circ} \mathrm{C} \sim 65{ }^{\circ} \mathrm{C}$ に外て、それ以下の温度では抑制されている FADの内部運動自由度は增加した。また、これらの变化は可逆的で あり、熱処理に引き続く $30^{\circ} \mathrm{C} 、 1$ 時間のインキュベーションの後、完 全に回復した。

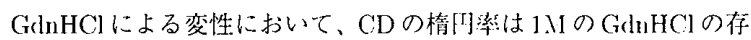
在下で低下し、定常状態での FAD 蛍光異方性は 0.jM の GdnHCl で 既に減少した。

今回、熱処理および、GdnHCl 処理について得られた結果を基に Lip-DH の構造安定性について議論する。

K. Meno, E. Nishimoto, T. Koga and S. Yamashita : Enfolding pro cess of Dihydrolipoamide dehyclrogenass"

\section{$3 \mathrm{~L} 1430$}

電子分光クライオ電子顕微鏡によるアクトミオシン 硬直複合体の高分解能構造

○安永 卓生 ${ }^{1}$ 、若林 健之 ${ }^{2}$ （ ${ }^{2}$ 九工大·情報工、2 帝京大·理工）

透過型電子顕微镜法を用いた構造解析も、2 次元稫晶を用いれば原 子モデル棈築が可能な段階となった。また、分子量が100万を超え る梯な複合体では、単粒子解析の手法により $1 \mathrm{~nm}$ を超える分解能が 奏現している。しかし、分子量 10 万程度の分子では、未だその分解 能が限られている。これは、クライオ電子顕微鏡法ではコントラスト が低いことが原因である。一方で、アクトミオシンのようなX線結晶 解析により原子モデルの得られている試料では、 $\alpha$ ヘリックスの配置 が認識できれば、両者の情報を組み合わせることにより原子レベル の議論が呵能である。そこで、我々は、アクチン・ミオシン複合体に

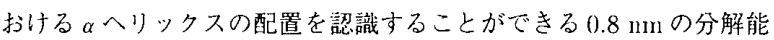
を目指すことを目的として、冷電界放出型電子鋶、エネルギーフィル 夕、高分解能高感度 CCD を備之た透過型電子顕微鏡電子顕微鏡法の 開発・画像処理法の開発を行ってきた。

昨年の年会に打いて、アクトミオシン硬直複合体の $0.8 \mathrm{~mm}$ を超え る高分解能像へ向けての研究の途中経過として、2 $\mathrm{mm}$ 程度の分解能 の像を報告した。電子分光法による画質の问上は著しく、単粒子解析 をはじめとする電子顕微鏡画像解析において有効であると考之られ た。電子顕微鏡法のさらなる改良と平均分子数の增大により、現在、 $1.5 \mathrm{~nm}$ を超える分解能を実現できている。年会ではサブナノメート 儿の分解能一问けて、方らに平均分子数を增やし、高分解能化を目指 す。また、分解能の構造を目指して、らせん対称性を仮定しない構造 解析についても試みているので、その成果について報告する。

T Yasumaga and T. Wakabayashi : High-resolution structure of ac: tomyosin rigor complex clucidated by electroscopic clectron cryomicroscopy

\section{$3 \mathrm{M} 0915$}

$$
\text { ニガウリトリプシンインヒビターの変性過程 }
$$

○高橋 大輔 ${ }^{1}$ 、古市 真木雄 ${ }^{3}$ 、西本悦子 ${ }^{2}$ 、水野洋 ${ }^{2}$ 、山下

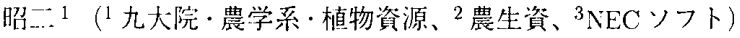
ニガウリ種子より得られるトリブシンインヒビター- (BGTI) は 68 個のアミノ酸残基からなる比較的コンパクトな構造をもつ蛋白質で ある。この間、このBGTIを用いて、その変性拉よびフォールディン グの過程について報告してきた。その中で、比較的小さな蛋白質にお いては考えにくいと思われた変性中間体がラクトアルブミン、リゾ チーム等と同様にグアニジン塩酸の $2 \mathrm{M}$ から $4 \mathrm{M}$ の濃度範囲に渡り確 認された。またBGTIの2つのTrp 残基のうちの1つは変性中間状態 においては、その運動性が抑えられると同時により疎水的環境下に㧈 かれ、逆に、他の Trp 残基は、上り親水的な雲囲気にさらされた。2 つの Trp残基が部位においてそれぞれ異なる変化を示した。この結果 は変性中間体の構造と特徽づける上で興味深い。定常状態抽よび時間 分割蛍光法は蛋白質の変性执よび折りたたみ構造を明らかにする.上で 有用であるが、得られた情報をさらに䇥量的にするために今回 BGTI の構造を決定した。二ガウリ種子より精製したBGTIを蒸気拡散法 により結晶化 (0.1.1 Na-Hepes, 0.8M Na-.K-Tatrate) し、0.8×0.8× $0.3 \mathrm{~mm}$ の結晶を得た。その結晶を用いてX線による構造解析行った。

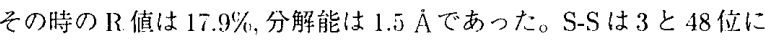
架橋され、分光学的解析に直接関わる Trp 9 の近傍には Gln 27、Lys 36 が配置されて抢り、Trp 9 の営光は強く消光されることが予想され る。もう 1 つの Trp残基である $\operatorname{Tr}, 5404$ A 以内に注大きな相互作 用示すアミノ酸残基は見あたらず、Trp 54 は溶媒に曝されていると いうことが何われる。今回決定された構造に基づき BGTI の変性過 程拉よび変性中間体のコンフォメーションについて考察する。

D. Takahashi, M. Furuichi, E. Nishimoto, H. Mizuno and S. Tamashita : Unfolding process of BCTI (III) 